\title{
PREDICTIVE EQUATION FOR BLOOD FLOW RESTRICTION TRAINING
}

\author{
EQUAÇÃO PREDITIVA PARA O TREINAMENTO DE RESTRIÇÃO DO FLUXO SANGUÍNEO
}

ECUACIÓN PREDICTIVA PARA EL ENTRENAMIENTO DE RESTRICCIÓN DEL FLUJO SANGUÍNEO

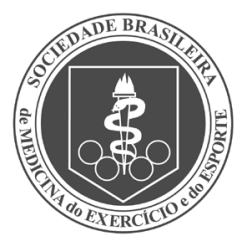

Original Article

Artigo Original

Artículo Original
Maria do Socorro Cirilo-Sousa' (Physical Education Professional) Jiddu Bastos Lemos

(Physical Education Professional) Rodrigo Poderoso'

(Physical Education Professional)

Ravi Cirilo Targino de Araújo

(Physical Education Professional)

Rodrigo Ramalho Aniceto

(Physical Education Professional)

Piettra Moura Galvão Pereira'

(Physical Education Professional)

Joamira Pereira Araújo ${ }^{1,2}$

(Physical Education Professional)

Pedro Henriques Marques Lucena' (Physical Education Professional)

Carlos Renato Paz ${ }^{1,3}$

(Physical Education Professional)

Adenilson Targino de Araújo Júnior ${ }^{1}$

(Physical Education Professional)

1. Department of Physical

Education, Associate Graduate

Program in Physical Education

UPE/ UFPB, Kinanthropometry and

Human Development Laboratory -

UFPB, João Pessoa, Paraíba, Brazil.

2. Department of Physical

Education, Instituto Federal do

Ceará (IFCE), Juazeiro do Norte,

Ceará, Brazil.

3. Department of Physical

Education, Instituto Federal da

Paraíba (IFPB), Campina Grande,

Paraíba, Brazil.

\section{Correspondence:}

Adenilson Targino de Araújo Júnior, Department of Physical Education, Kinanthropometry and Human Performance Laboratory, Universidade Federal da Paraíba (UFPB), Sala 06 e 08, Cidade Universitária, CEP: 58051-900, João Pessoa-PB, Brazil.

adenilsonjunior@yahoo.com.br

\begin{abstract}
Introduction: No research has investigated predictive equations for application in blood flow restriction (BFR) training using a cuff with a circumference of $18 \mathrm{~cm}$ for the lower limbs, and including age and sex as predictor variables. Objectives: To develop an equation to predict cuff pressure levels for use in BFR training for the lower limbs. Methods: A total of 51 adults (age $23.23 \pm 5.24$ years) of both sexes (males, $n=32$; females, $n=19$ ) underwent a series of tests and anthropometric (body mass, height, body mass index - BMl, and thigh circumference - TC) and hemodynamic (brachial systolic - SBP - and diastolic - DBP - blood pressure) measurements. The arterial occlusion pressure (AOP) of the lower limbs was measured using a Doppler probe. Results: The predictive equation was developed based on a hierarchical linear regression model consisting of six blocks, corresponding to TC $(\beta=0.380 ; p=0.005)$, SBP $(\beta=0.091 ; p=0.482)$, age $(\beta=0.320 ; p=0.015)$, and sex $(\beta=$ $-0.207 ; p=0.105$ ), which explained $39.7 \%$ of the variation in arterial occlusion pressure. DBP and BMI were not associated with AOP. As a result, the predictive equation is as follows: AOP $(\mathrm{mmHg})=65.290+1.110$ (TC in $\mathrm{cm})+0.178$ (SBP in $\mathrm{mmHg})+1.153$ (age in years) -7.984 (sex, 1 - male and $2-$ female), reporting values of $r=$ $0.630, r^{2}=0.397$ and SEE $=15,289$. Conclusion: Cuff pressure for BFR training of the lower limbs may be selected based on TC, SBP, age and sex, and thigh circumference is considered the main predictor. Level of Evidence III, Non-consecutive studies, or studies without consistently applied reference standard.
\end{abstract}

Keywords: Blood circulation; Muscle Strength; Strength Training; Rotator Cuff; Lower extremity.

\section{RESUMO}

Introdução: Nenhuma pesquisa investigou equações preditivas para aplicação no treinamento de restrição do fluxo sanguíneo (RFS) utilizando um manguito de $18 \mathrm{~cm}$ de circunferência para os membros inferiores e incluindo a idade e sexo como variáveis preditoras. Objetivos: Desenvolver uma equação preditiva dos níveis de pressão do manguito para uso no treinamento de RFS para os membros inferiores. Métodos: Um total de 51 adultos (23,23 \pm 5,24 anos) de ambos os sexos (homens, $n=32$; mulheres, $n=19$ ) foram submetidos a uma série de testes e medidas antropométricas (massa corporal, altura, índice de massa corporal - IMC e circunferência da coxa-CC) e hemodinâmicas (pressão sistólica braquial - PSB e diastólica-PDB). A pressão de oclusão arterial (POA) dos membros inferiores foi medida com utilização de uma sonda Doppler. Resultados: A equação preditiva foi desenvolvida a partir de um modelo hierárquico de regressão linear composto de seis blocos, correspondendo a CC $(\beta=0,380 ; p=0,005)$, PSB $(\beta=0,091 ; p=0,482)$, idade $(\beta=0,320 ; p=0,015)$ e sexo $(\beta=-0,207 ; p=0,105)$, explicando os $39,7 \%$ da variação na pressão de oclusão arterial. OIMC e a PDB não foram associados à POA. Como resultado, apresenta-se a seguinte equação: $P O A(\mathrm{mmHg})=65,290+1,110(\mathrm{CC}$ em cm) + 0,178 (PSB em mmHg) + 1,153 (idade em anos) - 7,984 (sexo, 1- masculino e 2-feminino), com valores de $r=0,630, r^{2}=0,397$ e EPE $=15,289$. Conclusão: A pressão do manguito para utilização no treinamento de RFS dos membros inferiores pode ser selecionada com base nas medidas de CC, PSB, idade e sexo, sendo que, a circunferência da coxa é considerada o principal preditor. Nível de Evidência III, Estudos não consecutivos ou estudos sem padrão de referência consistentemente aplicado.

Descritores: Circulação sanguínea; Força muscular; Treinamento de resistência; Manguito rotador; Membros inferiores.

\section{RESUMEN}

Introducción: Ninguna pesquisa investigó las ecuaciones predictivas para aplicación en el entrenamiento de restricción del flujo sanguíneo (RFS) utilizando un manguito de $18 \mathrm{~cm}$ de circunferencia para los miembros inferiores e incluyendo la edad y sexo como variables predictoras. Objetivos: Desarrollar una ecuación predictiva de los niveles de presión del manguito para uso en el entrenamiento de RFS para los miembros inferiores. Métodos: Un total de 51 adultos (23,23 $\pm 5,24$ años) de ambos sexos (masculino, $n=32$, femenino, $n=19$ ) fueron sometidos a una serie de pruebas y mediciones antropométricas (masa corporal, estatura, indice de masa corporal - IMCy circunferencia del muslo-CM) y hemodinámicas (presión sistólica braquial - PSB, y diastólica - PDB). La presión de oclusión arterial (POA) de los miembros inferiores se midió mediante una sonda Doppler. Resultados: La ecuación predictiva se desarrolló a partir de un modelo jerárquico de regresión lineal compuesto de seis bloques, correspondiendo a $C M(\beta=0,380$; $p=0,005)$, PSB $(\beta=0,091 ; p=0,482)$, edad $(\beta=0,320 ; p=0,015)$, y sexo $(\beta=-0,207 ; p=0,105)$, explicando $39,7 \%$ de la variación en la presión de oclusión arterial. EI IMC y la PDB no fueron asociadas a la POA. Como resultado, se presenta la siguiente ecuación: $P O A(\mathrm{mmHg})=65,290+1,110(\mathrm{CM}$ en cm) +0,178 (PAS en $\mathrm{mmHg})+1,153$ (edad 
en años) - 7,984 (sexo, 1 - Masculino y 2 - Femenino), con valores de $r=0,630, r^{2}=0,397$ y EEE $=15,289$. Conclusión: La presión del manguito para su uso en el entrenamiento de RFS de los miembros inferiores puede seleccionarse con base en las medidas de CM, PSB, edad y sexo, siendo que la circunferencia del muslo es considerada el principal predictor. Nivel de Evidencia III, Estudios no consecutivos o estudios sin estándar de referencia consistentemente aplicado.

Descriptores: Circulación sanguínea; Fuerza muscular; Entrenamiento de resistencia; Manguito de los rotadores; Miembros inferiores.

\section{INTRODUCTION}

Blood flow restriction (BFR) combined with low-load strength training (ST), has been widely reported to promote adaptations similar to the ones induced by high-load. 1,2 Despite the countless proven benefits, there is not yet a consensus on the BFR technique that ought to be prescribed, particularly regarding the amount of cuff pressure that should be applied to the body segments.

The studies have generally used $3-3.3 \mathrm{~cm}^{2}, 5 \mathrm{~cm}^{3}$ and $6 \mathrm{~cm}^{4}$ wide cuffs for the upper-body, and $5 \mathrm{~cm}^{3,5-9} 13.5 \mathrm{~cm}^{7,8} 18 \mathrm{~cm}^{1,10-13}$ and $18.5^{2,14}$ for the lower-body. Additionally, several pressure regimens have been tested, including fixed pressures of $50 \mathrm{mmHg}^{15} 150 \mathrm{mmHg}^{16}$ and 200 $\mathrm{mmHg}^{9}$ and gradual increasing pressures from 160 to $200 \mathrm{mmHg}, 160$ to $230 \mathrm{mmHg} .{ }^{17}$ Pressures calculated using equations, such as the systolic arterial pressure at rest multiplied by $1.3^{14,18}$ or $1.44^{19,20}$; and $50 \%{ }^{1,11}$ or $80 \%$ 4,10,21 of the "total" or maximum resting arterial occlusion pressure.

The reason for these variance is that the amount of tissue that surrounds the blood vessels influences the pressure that is applied. In turn, the cuff pressure selected based on the arterial occlusion pressure at rest measured with a Doppler probe is widely used. 1,4,6,7,1013,21 However, Doppler probe are expensive and properly trained technicians to operate. For these reasons, more accessible methods are needed, for instance, regression equations including variables liable to interfere with the cuff pressure, such as sociodemographic (sex, age), anthropometric (body mass index - BMI, thigh circumference - TC) and hemodynamic (systolic and diastolic blood pressures - SBP and DBP) parameters.

Loenneke et al. ${ }^{6}$ formulated various regression equations for the aforementioned purpose, but, they did not include $\operatorname{sex}_{1}{ }^{22,23} \mathrm{age}_{1}{ }^{22-24}$ and $\mathrm{BM}^{22,25}$ in the predictive models. Additionally, one study included sex, race and different widths of cuffs $(5 \mathrm{~cm}, 10 \mathrm{~cm}$ and $12 \mathrm{~cm})$ for upper limbs, ${ }^{26}$ and another study included a cuffs of $13 \mathrm{~cm},{ }^{25}$ but no study has investigated predictive equations using a wider cuff in the lower limbs using together both age and sex as predictor variables.

Therefore, the aim of the present study was to develop an equation to predict the pressure of the 18 -cm wide cuff to prescribe BFR training for the lower limbs. It was hypothesized that BFR estimated based on arterial occlusion pressure (AOP) should be determined by sociodemographic, anthropometric and hemodynamic variables.

\section{METHODS}

\section{Subjects}

The sample consisted of 51 apparently healthy adults (males, $n=32$; females, $n=19$ ), Table 1. Individuals with any cardiovascular, metabolic and/or musculoskeletal problems, using dietary supplements, medications and/or nicotine were excluded.

The procedures used in this study were approved by the Institutional Review Board at the Federal University of Paraiba (\#0389/11). Written informed consent was obtained from each subject prior to the investigation.
Table 1. Descriptive characteristics of the subjects $(n=51)$.

\begin{tabular}{c|c|c}
\hline Variables & Mean \pm Standard deviation & Minimum-Maximum \\
\hline Age (years) & $28 \pm 7$ & $18-47$ \\
\hline Body mass $(\mathrm{kg})$ & $69.58 \pm 14.79$ & $48,40-106.00$ \\
\hline Height $(\mathrm{cm})$ & $169.86 \pm 9.59$ & $153.20-190.20$ \\
\hline BMI $\left(\mathrm{kg} / \mathrm{m}^{2}\right)$ & $24.02 \pm 4.12$ & $16.54-34.45$ \\
\hline $\mathrm{TC}(\mathrm{cm})$ & $58.20 \pm 6.46$ & $47.00-74.00$ \\
\hline $\mathrm{SBP}(\mathrm{mmHg})$ & $119 \pm 9$ & $100-146$ \\
\hline $\mathrm{DBP}(\mathrm{mmHg})$ & $74 \pm 10$ & $50-104$ \\
\hline $\mathrm{AOP}(\mathrm{mmHg})$ & $166 \pm 18$ & $144-237$ \\
\hline
\end{tabular}

$\mathrm{BMI}=$ body mass index; $\mathrm{TC}=$ thigh circumference; $\mathrm{SBP}=$ brachial systolic blood pressure; $\mathrm{DBP}=$ brachial diastolic blood pressure; $\mathrm{AOP}=$ arterial occlusion pressure.

\section{Study design}

This investigation examined whether the pressure of BFR can be predicted by the subjects'sociodemographic, anthropometric and hemodynamic variables. A cross-sectional design was used to observe the relations between the variables and to develop a predictive equation for pressure BFR. The independent (predictor) variables were sex, age (years), body mass index (BMI, $\left.\mathrm{kg} / \mathrm{m}^{2}\right)$, thigh circumference $(\mathrm{cm})$, brachial SBP $(\mathrm{mmHg})$ and brachial DBP $(\mathrm{mmHg})$. Arterial occlusion pressure ( $\mathrm{mmHg}$ ) was the dependent (predicted) variable.

The participants were subjected to a series of tests in the laboratory after collecting the data corresponding to the sociodemographic (age and sex) and anthropometric (BM, height and TC) variables. The participants were then asked to rest for 10 minutes on an exam table in dorsal decubitus, with the arms to the sides of the body and the legs uncrossed. Next, the AOP was measured in the lower limbs in a random and counterbalanced manner. The hemodynamic parameters (SBP and DBP) were measured three minutes later.

Data collection was performed in the morning to avoid variations related to the circadian rhythm. The participants arrived at the laboratory with at least two hours of a post absorptive state, having been instructed to hydrate themselves and sleep normally and to abstain from exercise, caffeine and alcohol for at least 24 hours before the tests.

\section{PROCEDURES}

\section{Anthropometric measurements}

Body mass (BM, kg) and height $(\mathrm{cm})$ were respectively measured using a digital scale (Filizola, Brazil) and stadiometer (Wiso, E210, Brazil). Proximal TC (cm) was measured using an anthropometric tape (Cardiomed, Curitiba, Paraná, Brazil) in the point of the gluteal fold.

\section{Hemodynamic measurements}

Brachial SBP $(\mathrm{mmHg})$ and DBP $(\mathrm{mmHg})$ were measured using an automatic blood pressure monitor (Model HEM-705 CP, OMRON, Japan). 4, 10,21 Three measurements were performed at one-minute intervals, and the mean of the last two was calculated.

\section{Measurement of the arterial occlusion pressure}

Subjects were asked to lay down in a supine position while resting comfortably for 10 minutes. Then, a vascular Doppler (Medpej DV-2001, 
Ribeirão Preto, São Paulo, Brazil) probe was placed over the tibial artery to determine the AOP $(\mathrm{mmHg})$ of the subject. A standard blood pressure cuff $(80 \mathrm{~cm} \text { length } \times 18 \mathrm{~cm} \text { width) })^{1,10-13}$ attached to the thigh proximal portion (inguinal fold region) was inflated gradually in increments of 20 $\mathrm{mmHg}$ up to the point at which the auscultatory pulse of the tibial artery was interrupted:4,21 the cuff was inflated an additional $20 \mathrm{mmHg}$ and then deflated at a rate of $5 \mathrm{mmHg}$ every 10 seconds to confirm the AOP value.

\section{Statistical analyses}

The sample size was calculated using the program $\mathrm{G}^{*}$ Power 3.1.9.2, ${ }_{1}^{27}$ with an effect size $\left(f^{2}\right)$ of 0.60 , a power of $0.80(B=0.20)$ and a two-tailed significance level (a) of 0.05 , it was established that at least 30 participants were needed to develop a regression equation for the BFR pressure considering the six predictor variables. Statistical analysis was performed using SPSS 16.0 (IBM SPSS, Inc., Chicago, IL, USA). Pearson's correlation was used to test the bivariate relationship between predictor and predicted variables. The predictive equation was developed by means of a hierarchical linear regression model, which consisted of six individual blocks ranked according to the distal and proximal determinants, as depicted in Figure 1. According to our selected theoretical framework, the variables were hierarchically inserted into the model by their influence on the AOP. In this regard, TC was inserted in the first block, once we believe that it is the main AOP predictor, ${ }^{3,6,7,28}$ and following, for the remaining blocks, $\mathrm{SBP}_{1}^{6,7,14,18-20} \mathrm{DBP}, 6,7,25$ age, $^{22-24} \mathrm{BMI}^{22,25}$ and sex ${ }^{22,23}$ were added, respectively. (Figure 1) While all of the variables were considered in the elaboration of the adjusted model, only the ones with $p$ values $<0.20$ in input to model were kept. Changes in Pearson correlation, part correlation coefficient (PCC), $r^{2}$, standard error of the estimate (SEE), and F-value were determined for each block. Also in each block, collinearity between variables was assessed based on the variance inflation factor (VIF) and tolerance (T) values with cutoff points of less than 5 and greater than 0.1 , respectively. ${ }^{29}$

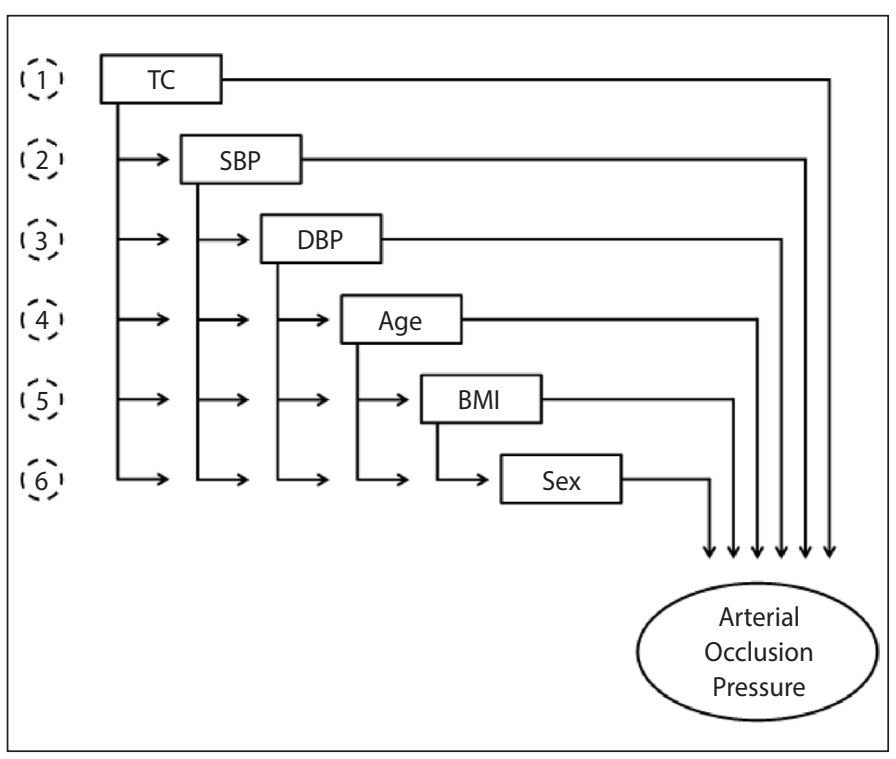

Figure 1. Block hierarchical theoretical model used to develop the equation to predict the blood flow restriction pressure in the lower limbs.

\section{RESULTS}

The mean \pm standard deviation of the lower limb AOP was $166 \pm 18$ mmHg. (Table 1) Table 2 describes the Pearson's correlation coefficient values corresponding to the assessed variables. There were positive relationships between some of the predictor (age, TC, sex and SBP) and the predicted variables. DBP and BMI were not associated with AOP $(p>0.05)$. TC exhibited the highest correlation coefficient $(r=0.506)$, which corresponds to a moderate relationship with AOP.
The variables TC, SBP, age and sex were included in the first, second, third and fourth blocks, respectively; TC explained $25.6 \%$ of the variation in AOP; TC and SBP explained 29.1\%; TC, SBP and age explained 36.1\%; and TC, SBP, age and sex explained $39.7 \%$. (Table 3) None of the variables met the criteria for collinearity. As a result, the predictive equation as follows: - $\mathrm{AOP}(\mathrm{mmHg})=65.290+1.110(\mathrm{TC}$ in $\mathrm{cm})+0.178(\mathrm{SBP}$ in $\mathrm{mmHg})+$ 1.153 (age in years) - 7.984 (sex, 1 - male; 2 - female).

- Where = AOP: arterial occlusion pressure; TC: thigh circumference; and SBP: brachial systolic blood pressure.

Table 2. Pearson's correlation coefficients between predictor and predicted variables $(n=51)$.

\begin{tabular}{c|c|c|c|c|c|c}
\hline \multirow{2}{*}{$\begin{array}{c}\text { Predicted variable } \\
\text { (dependent) }\end{array}$} & \multicolumn{5}{|c}{ Predictor variables (independent) } \\
\cline { 3 - 7 } & $\begin{array}{c}\text { Age } \\
\text { (years) }\end{array}$ & TC $(\mathbf{c m})$ & $\begin{array}{c}\text { BMl } \\
\left(\mathbf{k g} / \mathbf{m}^{2}\right)\end{array}$ & $\begin{array}{c}\text { SBP } \\
(\mathbf{m m H g})\end{array}$ & $\begin{array}{c}\text { DBP } \\
(\mathbf{m m H g})\end{array}$ \\
\hline \multirow{2}{*}{$\mathrm{AOP}(\mathrm{mmHg})$} & $\mathrm{r}$ & 0.452 & 0.506 & 0.438 & 0.307 & 0.224 \\
\cline { 2 - 7 } & $\mathrm{p}$ & 0.001 & $<0.001$ & 0.001 & 0.028 & 0.115 \\
\hline
\end{tabular}

$\mathrm{BMI}=$ body mass index; $\mathrm{TC}=$ thigh circumference; $\mathrm{SBP}=$ brachial systolic blood pressure; $\mathrm{DBP}=$ brachial diastolic blood pressure; $\mathrm{AOP}=$ arterial occlusion pressure.

Table 3. Hierarchical linear regression model to predict arterial occlusion pressure in the lower limbs $(n=51)$.

\begin{tabular}{|c|c|c|c|c|c|c|c|c|c|c|}
\hline Blocks & Variables & $\begin{array}{c}\text { Stand. } \\
\beta\end{array}$ & $p$ & PCC & $r$ & $r^{2}$ & SEE & $\begin{array}{c}\text { Sig. F } \\
\text { change }\end{array}$ & $\mathrm{T}$ & VIF \\
\hline 1 & $\mathrm{TC}$ & 0.506 & $<0.001$ & 0.506 & 0.506 & 0.256 & 16.446 & $<0.001$ & 1.000 & 1.000 \\
\hline \multirow{2}{*}{2} & $\mathrm{TC}$ & 0.458 & 0.001 & 0.444 & \multirow{2}{*}{0.540} & \multirow{2}{*}{0.291} & \multirow{2}{*}{16.222} & \multirow{2}{*}{$<0.001$} & 0.938 & 1.067 \\
\hline & SBP & 0.193 & 0.131 & 0.187 & & & & & 0.938 & 1.067 \\
\hline \multirow[t]{3}{*}{3} & $\mathrm{TC}$ & 0.353 & 0.009 & 0.319 & \multirow{3}{*}{0.601} & \multirow{3}{*}{0.361} & \multirow{3}{*}{15.568} & \multirow{3}{*}{$<0.001$} & 0.817 & 1.224 \\
\hline & SBP & 0.170 & 0.166 & 0.164 & & & & & 0.931 & 1.074 \\
\hline & Age & 0.287 & 0.028 & 0.264 & & & & & 0.846 & 1.183 \\
\hline \multirow[t]{4}{*}{4} & $\mathrm{TC}$ & 0.380 & 0.005 & 0.341 & \multirow{4}{*}{0.630} & \multirow{4}{*}{0.397} & \multirow{4}{*}{15.289} & \multirow{4}{*}{$<0.001$} & 0.804 & 1.245 \\
\hline & SBP & 0.091 & 0.482 & 0.081 & & & & & 0.801 & 1.249 \\
\hline & Age & 0.320 & 0.015 & 0.291 & & & & & 0.824 & 1.213 \\
\hline & Sex & -0.207 & 0.105 & -0.189 & & & & & 0.840 & 1.190 \\
\hline
\end{tabular}

$\mathrm{TC}=$ thigh circumference; $\mathrm{SBP}=$ brachial systolic blood pressure; $\mathrm{DBP}=$ brachial diastolic blood pressure; $\mathrm{PCC}$ part correlation coefficient; $\mathrm{SEE}=$ standard error of the estimate; $\mathrm{VIF}=$ variance inflation factor; $\mathrm{T}=$ tolerance.

\section{DISCUSSION}

In this study, an equation was developed to predict the cuff pressure to be used in BFR of the lower limbs based on the arterial occlusion pressure (AOP), based on factors such as thigh circumference, $3,6,7,26,28$ brachial systolic blood pressure, 6,7,14,18-20,26 age, 22-24 and sex. ${ }^{22,23}$ Established on the crude hierarchical regression model, the explanatory power of the block that included only TC was $25.6 \%$. When the variables TC, SBP, age and sex were included, the explanatory power (39.7\%) and the effect size $(r=0.630)$ increased. These findings indicate that the final adjusted model exhibits high practical applicability for professionals in this field, and that the pressure used for BFR should be more strongly based on $\mathrm{TC}$ rather than on other measures mentioned in the literature. 6,7,26

To our knowledge, regression equations to predict the cuff pressure for BFR training in lower limbs were developed in two studies ${ }^{6,25}$ and one to upper limbs. ${ }^{26}$ Loenneke et al., ${ }^{6}$ based on a hierarchical model to define the AOP of the lower limbs, SBP, and TC were used. It is worthwhile to observe that DBP was the variable that less influenced their model $(\beta=0.139 ; p=0.131)$, which agrees with the results of the present study, in which DBP and BMI was excluded from the final adjusted model.

One further point that should be stressed is that the SEE in the blocks of our study was lower compared to that reported by Loenneke et al., ${ }^{6}$ demonstrating that the external validity of the model elaborated in the present study is larger. On the other hand, cuff size was a factor that might have influenced the SEE, was used an $18-\mathrm{cm}$ wide cuff and we found a SEE below 20.0, as found by Loenneke et al., ${ }^{7}$ which used a 13.5-cm wide cuff. However, when Loenneke et al. ${ }^{6,7}$ used a 5-cm wide 
cuff, they found SEE values above 20.0. Cuffs with different width may impact the measurement of the AOP. ${ }^{7}$ Crenshaw et al. ${ }^{28}$ demonstrated that the wider the cuff, the lower the pressure required to occlude circulation.

In the present study, another relevant variables, age and sex, was added, which makes it possible to extrapolate the equation to the populations, because the vascular system might change as a function of them, ${ }^{23,24}$ and not considered by previous research ${ }^{6,25}$, only sex was inserted by Jesse et al. ${ }^{26}$ In this way, it is observed that the standardized beta values of this study $(\beta=-0.207 ; p=0.105)$ and the study of Jesse et al. ${ }^{26}$ (2016) to cuffs of $10 \mathrm{~cm}$ and $12 \mathrm{~cm}(\beta=0.227, p<0.001 ; \beta=0.246, p$ $<0.001$; respectively) are similar, possibly this occurred due the similarity of the anthropometric characteristics.

In the analysis of the correlation between the independent and the dependent variable, TC exhibited a moderate correlation $(r=0.506 ; p$ $=0.001)$ compared to SBP $(r=0.307 ; p=0.028)$, and DBP $(r=0.224 ; p$ $=0.115)$. These findings corroborate those of Loenneke et al. ${ }^{7}$ (2012a), which indicate that the amount of the fat and muscle surrounding the blood vessels may have a more direct effect on the level of pressure needed to block the venous blood flow and to reduce the arterial blood flow compared to the arterial pressure.

In addition to measuring TC, Loenneke et al. ${ }^{7}$ analyzed the muscle and fat areas in the thigh using computed tomography and found that the explanatory power relative to the dependent variable was greater, and that in the heaviest participants exhibited high values or could not be established because it was beyond the device capacity $(300 \mathrm{mmHg}$ ), which demonstrates the need to use TC as a parameter. The same AOP value applied to limbs with different circumferences will differ at the vascular level because the amount of tissue that surrounds the vessels influences the pressure that is applied to them.?
The presents results show that the sample heterogeneity complies with the principle of data variability relative to the sociodemographic, anthropometric and hemodynamic variables. However, one of the limitations is that the equation was developed exclusively for the lower-body and for the 18-cm wide cuffs. Therefore, further studies ought to be performed with both the upper and lower limbs, and also needed to investigate the reproducibility of this model, along with the one developed by Loenneke et al., ${ }^{6}$ Hunt et al. ${ }^{25}$ and Jesse et al., ${ }^{26}$ in different populations.

In the end, this study fills a gap in the available knowledge through the development of a new equation to estimate AOP that includes novel variables. The equation presented here might represent a practical and low-cost option to identify the BFR pressure for professionals who perform training with larger cuffs.

\section{CONCLUSION}

In conclusion, the cuff pressure for lower limb BFR training may be selected based on thigh circumference (TC), brachial systolic blood pressure (SBP), age and sex, and TC is the best predictor of arterial occlusion pressure (AOP). BFR is being increasingly used in several exercise modalities and by various population groups, thus, need to use a practical and accessible method to select the cuff pressure for the lower limbs under different circumstances.

\section{ACKNOWLEDGMENTS}

No financial assistance was obtained for this study.

All authors declare no potential conflict of interest related to this article

AUTHORS' CONTRIBUTIONS: Each author made significant individual contributions to this manuscript. MSCS (0000-0001-5566-3248)*: writing of the article, study design and data collection; JBL (0000-0002-8883-926X)*: data analysis, writing of the article and final approval; RP (0000-0002-7590-3015)*: writing and review of the article; RCTA (0000-0002-83866293)*: study design and data collection; RRA (0000-0002-7253-8331)*: data collection and writing of the article; PMGP (0000-0002-7278-2385)*: critical and grammatical review of the article; JPA (0000-0002-9177-7581)*: research project advisor and final approval; PHML (0000-0003-3264-1358); CRP (0000-0001-9733-2105)*: critical review and data interpretation; ATAJ (0000-0002-3857-681X)* writing of the article and final approval. *ORCID (Open Researcher and Contributor ID).

\section{REFERENCES}

1. Laurentino GC, Ugrinowitsch C, Roschel H, Aoki MS, Soares AG, Neves Jr M, et al. Strength training with blood flow restriction diminishes myostatin gene expression. Med Sci Sports Exerc. 2012;44(3):406-12.

2. Takarada Y, Takazawa H, Sato Y, Takebayashi S, Tanaka Y, Ishii N. Effects of resistance exercise combined with moderate vascular occlusion on muscular function in humans. J Appl Physiol. 2000;88(6):2097-106.

3. Loenneke JP, Kim D, Fahs CA, Thiebaud RS, Abe T, Larson RD, et al. Effects of exercise with and without different degrees of blood flow restriction on torque and muscle activation. Muscle Nerve. 2015;51(5):713-21.

4. Neto GR, Sousa MSC, Costa e Silva GV, Gil ALS, Salles BF, Novaes JS. Acute resistance exercise with blood flow restriction effects on heart rate, double product, oxygen saturation and perceived exertion. Clin Physiol Funct Imaging. 2016;36(1):53-9.

5. Fahs CA, Rossow LM, Loenneke JP, Thiebaud RS, Kim D, Bemben DA, et al. Effect of different types of lower body resistance training on arterial compliance and calf blood flow. Clin Physiol Funct Imaging. 2012;32(1):45-51

6. Loenneke JP, Allen KM, Mouser JG, Thiebaud RS, Kim D, Abe T, et al. Blood flow restriction in the upper and lower limbs is predicted by limb circumference and systolic blood pressure. Eur J Appl Physiol. 2015;115(2):397-405.

7. Loenneke JP, Fahs CA, Rossow LM, Sherk VD, Thiebaud RS, Abe T, et al. Effects of cuff width on arterial occlusion: implications for blood flow restricted exercise. Eur J Appl Physiol. 2012;112(8):2903-12.

8. Rossow LM, Fahs CA, Loenneke JP, Thiebaud RS, Sherk VD, Abe T, et al. Cardiovascular and perceptual responses to blood-flow-restricted resistance exercise with differing restrictive cuffs. Clin Physiol Funct Imaging. 2012;32(5):331-7.

9. Rossow LM, Fahs CA, SherkVD, Seo DI, Bemben DA, Bemben MG. The effect of acute blood-flow-restricted resistance exercise on postexercise blood pressure. Clin Physiol Funct Imaging. 2011;31(6):429-34

10. Araujo JP, Silva ED, Silva JC, Souza TS, Lima EO, Guerra I, et al. The acute effect of resistance exercise with blood flow restriction with hemodynamic variables on hypertensive subjects. J Hum Kinet. 2014;43(1):79-85.

11. Gualano B, Ugrinowitsch C, Neves Jr M, Lima FR, Pinto ALS, Laurentino G, et al. Vascular occlusion training for inclusion body myositis: a novel therapeutic approach. J Vis Exp. 2010;40:e1894

12. Pinto RR, Polito MD. Haemodynamic responses during resistance exercise with blood flow restriction in hypertensive subjects. Clin Physiol Funct Imaging. 2016;36(5):407-13.

13. Poton R, Polito MD. Hemodynamic response to resistance exercise with and without blood flow restriction in healthy subjects. Clin Physiol Funct Imaging. 2016;36(3):231-6.
14. Suga T, Okita K, Morita N, Yokota T, Hirabayashi K, Horiuchi M, et al. Dose effect on intramuscular metabolic stress during low-intensity resistance exercise with blood flow restriction. J Appl Physiol. 2010;108(6):1563-7.

15. Kubota A, Sakuraba K, Koh S, Ogura Y, Tamura Y. Blood flow restriction by low compressive force prevents disuse muscular weakness. J Sci Med Sport. 2011;14(2):95-9.

16. Inagaki $Y$, Madarame $\mathrm{H}$, Neya $\mathrm{M}$, Ishii N. Increase in serum growth hormone induced by electrical stimulation of muscle combined with blood flow restriction. Eur J Appl Physiol. 2011;111(11):2715-21.

17. Abe T, Kearns CF, Sato Y. Muscle size and strength are increased following walk training with restricted venous blood flow from the leg muscle, Kaatsu-walk training. J Appl Physiol. 2006;100(5):1460-6.

18. Cook SB, Clark BC, Ploutz-Snyder LL. Effects of exercise load and blood-flow restriction on skeletal muscle function. Med Sci Sports Exerc. 2007;39(10):1708-13.

19. Karabulut M, Cramer JT, Abe T, Sato Y, Bemben MG. Neuromuscular fatigue following low-intensity dynamic exercise with externally applied vascular restriction. J Electromyogr Kinesiol. 2010;20(3):440-7.

20. Karabulut M, Leal JA, Garcia SD, Cavazos C, Bemben M. Tissue oxygenation, strength and lactate response to different blood flow restrictive pressures. Clin Physiol Funct Imaging. 2014;34(4):263-9.

21. Neto GR, Sousa MSC, Costa PB, Salles BF, Novaes GS, Novaes JS. Hypotensive effects of resistance exercises with blood flow restriction. J Strength Cond Res. 2015;29(4):1064-70.

22. Drøyvold WB, Midthjell K, Nilsen TI, Holmen J. Change in body mass index and its impact on blood pressure: a prospective population study. Int J Obes (Lond). 2005;29(6):650-5.

23. Joyner MJ, Wallin BG, Charkoudian N. Sex differences and blood pressure regulation in humans. Exp Physiol. 2016;101(3):349-55.

24. Wei JY. Age and the cardiovascular system. N Engl J Med. 1992;327(24):1735-9.

25. Hunt JEA, Stodart C, Ferguson RA. The influence of participant characteristics on the relationship between cuff pressure and level of blood flow restriction. Eur J Appl Physiol. 2016;116(7):1421-32.

26. Jessee MB, Buckner SL, Dankel SJ, Counts BR, Abe T, Loenneke JP. The influence of cuff width, sex, and race on arterial occlusion: implications for blood flow restriction research. Sports Med. 2016;46(6):913-21.

27. Faul F, Erdfelder E, Buchner A, Lang AG. Statistical power analyses using G*Power 3.1 : tests for correlation and regression analyses. Behav Res Methods. 2009;41(4):1149-60.

28. Crenshaw AG, Hargens AR, Gershuni DH, Rydevik B. Wide tourniquet cuffs more effective at lower inflation pressures. Acta Orthop Scand. 1988;59(4):447-51.

29. Snee RD. Validation of regression models: methods and examples. Technometrics. 1977;19(4):415-28. 